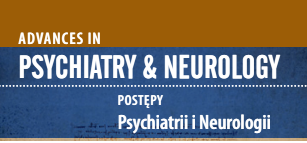

Correspondence to/ Adres do korespondencji:

prof. Jan Chodkiewicz Zakład Psychologii Zdrowia

Wydział Nauk o Wychowaniu

Instytut Psychologii

Uniwersytet Łódzki

ul. Smugowa 10/12

91-433 Łódź

tel. 605346935

e-mail: janchodkiewicz@poczta.onet.pl

Submitted/Otrzymano: 18.09.2016

Accepted/Przyjęto do druku: 20.12.2016

\section{POLISH ADAPTATION OF THE GOTLAND SCALE OF MALE DEPRESSION (GDMS) BY WOLFGANG RUTZ}

\author{
POLSKA ADAPTACJA GOTLANDZKIEJ \\ SKALI MĘSKIEJ DEPRESJI (GDMS) \\ WOLFGANGA RUTZA
}

\author{
Jan Chodkiewicz \\ Institute of Psychology, Department of Health Psychology, Faculty of Educational \\ Sciences, University of Lodz, Lodz, Poland \\ Zakład Psychologii Zdrowia, Wydział Nauk o Wychowaniu, Instytut Psychologii, \\ Uniwersytet Łódzki, Łódź, Polska
}

\begin{abstract}
Purpose: The concept of male depression by W. Rutz assumed the dominance, in the clinical picture of depression, atypical symptoms, especially anger, aggressive and risky behavior and the use of alcohol and other psychoactive substances instead of depressed mood and inactivity. One method for measuring this kind of depression is the Gotland Scale of Male Depression (GDMS). The aim of the study was Polish adaptation of the scale.

Methods: The study involved a total of 551 men. Among them, in 400, there were no mental disorders (at present and in the past) and serious somatic illnesses. Also examined 60 men diagnosed with depression, and 91 alcohol-dependent. The validated method, Beck Depression Inventory (BDI), General Health Questionnaire - GHQ-28 (subscale - symptoms of depression) and Scale of Psychache by Holden et al. were used in the study.

Results: Exploratory factor analysis (EFA) and confirmatory factor analysis (CFA) indicated that the Polish version of the method is characterized by a one factor structure. Item number 13 correlates with general score very poorly. Cronbach's $\alpha$ coefficient ranged from 0.85 in the healthy control group to 0.88 in patients with alcohol dependence. GDMS had a strong relationship with BDI and the GHQ28 (depression subscale). The method differentiate healthy people, addicted to alcohol and people with depression very properly.

Conclusions: Polish version of the method is characterized by satisfactory reliability and validity. The method can be recommended for use in both scientific research and screening as well.
\end{abstract}

Key words: male depression, scale GDMS, Polish adaptation.

\title{
Streszczenie
}

Cel: Koncepcja męskiej depresji W. Rutza zakłada dominację w obrazie klinicznym depresji objawów atypowych, przede wszystkim złości, zachowań agresywnych i ryzykownych oraz używania alkoholu i innych substancji psychoaktywnych w miejsce obniżenia nastroju i braku aktywności. Jedną z metod pomiaru tej depresji jest Gotlandzka Skala Męskiej Depresji (Gotland Male Depression Scale - GDMS). Celem przeprowadzonych badań była polska adaptacja tej skali.

Metody: W badaniach wzięło udział łącznie 551 mężczyzn. Wśród nich u 400 nie występowały obecnie ani w przeszłości zdiagnozowane zaburzenia psychiczne i poważne choroby somatyczne. Zbadano również 60 mężczyzn ze zdiagnozowaną depresją oraz 91 uzależnionych od alkoholu. W badaniach, obok walidowanej metody, zastosowano Inwentarz Depresji Becka (Beck Depression Inventory - BDI), Kwestionariusz Ogólnego Stanu Zdrowia Goldberga (podskalę - objawy depresji) (General Health Questionnaire - subscale - symptoms of depression - GHQ-28) oraz Skalę Bólu Psychicznego Holdena i wsp.

Wyniki: Eksploracyjna analiza czynnikowa oraz analiza konfirmacyjna wskazują, że polska wersja metody charakteryzuje się strukturą jednoczynnikową. Pozycja 13. najsłabiej koreluje z wynikiem ogólnym. Współczynnik a Cronbacha wynosił od 0,85 w grupie osób zdrowych do 0,88 w grupie osób uzależnionych od alkoholu. Skala GDMS wykazuje silne związki z BDI oraz GHQ-28 - podskalą depresji. Metoda dobrze różnicuje osoby zdrowe, uzależnione od alkoholu i z rozpoznaną depresją.

Wnioski: Polska wersja metody charakteryzuje się zadowalającą rzetelnością i trafnością. Metodę można polecać zarówno do stosowania w analizach naukowych, jak i w badaniach przesiewowych.

Słowa kluczowe: męska depresja, skala GDMS, polska adaptacja. 


\section{INTRODUCTION}

Attention to the possibility of the occurrence of different symptoms of depression in men and women was drawn as late as at the end of the $20^{\text {th }}$ century. Reasons for the interest in the issue mainly include the differences with respect to the diagnosis of depression, considerably more common in women as compared to the significantly larger number of suicidal deaths in men [1-4].

The experience of the early diagnosis and treatment of depression and suicide prevention program on the island of Gotland (Sweden) also proved to be relevant. The program focused on the typical symptoms of depression and resulted in positive changes regarding the frequency of suicidal behaviour and the diagnosis and treatment of depression in women, little changed in this respect in the case of men. The evaluation of the program resulted in the authors' conclusion that the differences between the male and female symptoms in the depressive disorder are the cause, which results in difficulties with respect to the proper diagnosis and treatment of male patients. The main differences were perceived in the domination of atypical symptoms in many depressed men, especially anger, irritability, aggressive and risky behaviour as well as use of alcohol and other psychoactive substances instead of depressed mood and lack of activity [e.g. 5, 6].

The study of male atypical depression utilizes several created measurement tools, including the most famous Gotland Male Depression Scale (GMDS) by W. Rutz [7, 8]. The method was initially conceived as a screening tool designed for primary care physicians. It gained great popularity; it is used in numerous scientific studies and has been adapted in several countries, such as Italy, China and Iceland [9-13]. For these reasons, it was decided to carry out the Polish validation of the tool, which was the aim of the present study.

\section{METHODS}

The validated method was the Gotland Male Depression Scale. The scale consists of 13 statements describing the depressive symptoms of the people examined a month before. The items relate to both the typical symptoms of depression, such as anxiousness, sleep disorders, fatigue, difficulty in making decisions, tendency to selfpity and the atypical symptoms, i.e. feeling excessive stress, burnout and frustration, difficulty in self-control, abusing alcohol and drugs, activity increased by excessive work and/or exercise as well as changes in the current functioning, as noted by the subjects and close relatives. The last item refers to the occurrence similar tendencies in the family members, i.e. to feel down or depressed, to attempt suicide and being prone to risk behaviours. Each of the statements is scored on the four-point Likert

\section{WSTĘP}

Na możliwość występowania odmiennych objawów depresji u mężczyzn i kobiet zwrócono uwagę dopiero pod koniec XX w. Wśród przyczyn zainteresowania tą problematyką wymienia się przede wszystkim różnice w odniesieniu do diagnozowania zaburzeń depresyjnych, które notuje się istotnie częściej u kobiet, w porównaniu ze znacząco większą liczbą zakończonych śmiercią prób samobójczych u mężczyzn [1-4].

Istotne okazały się również doświadczenia wprowadzonego na Gotlandii (Szwecja) programu wczesnego diagnozowania i leczenia depresji oraz prewencji samobójstw. Program, skoncentrowany na typowych objawach depresji, doprowadził do korzystnych zmian odnośnie do częstości zachowań suicydalnych oraz rozpoznawania i leczenia depresji u kobiet, niewiele zmieniając $\mathrm{w}$ tym zakresie w przypadku mężczyzn. Ewaluacja programu doprowadziła autorów do wniosku, że przyczyną są różnice objawów między męskim i żeńskim zespołem depresyjnym, co prowadzi do trudności w prawidłowym diagnozowaniu i leczeniu pacjentów płci męskiej. Podstawowych różnic upatrywano $\mathrm{w}$ dominacji u wielu depresyjnych mężczyzn objawów atypowych, przede wszystkim złości, drażliwości, zachowań agresywnych i ryzykownych, oraz w używaniu alkoholu i innych substancji psychoaktywnych w miejsce obniżenia nastroju i braku aktywności [m.in. 5, 6].

Do badania atypowej męskiej depresji stworzono kilka narzędzi pomiaru, wśród których najbardziej znana jest Gotlandzka Skala Męskiej Depresji (Gotland Male Depression Scale - GMDS) W. Rutza [7, 8]. Metoda, pomyślana początkowo jako narzędzie przesiewowe przeznaczone dla lekarzy pierwszego kontaktu, zdobyła sobie dużą popularność, zastosowano ją w licznych badaniach naukowych oraz dokonano adaptacji w kilku krajach, np. we Włoszech, Chinach i na Islandii [9-13]. Z powyższych przyczyn zdecydowano się na przeprowadzenie polskiej walidacji narzędzia, co było celem prezentowanego badania.

\section{METODY}

Walidowaną metodą była Gotlandzka Skala Męskiej Depresji. Składa się ona z 13 twierdzeń opisujących objawy depresji występujące u osoby badanej w ciągu ostatniego miesiąca. Pozycje dotyczą zarówno typowych objawów depresji, takich jak odczuwanie niepokoju, problemów ze snem, zmęczenia, trudności z podejmowaniem decyzji, tendencji do użalania się nad sobą, jak i symptomów atypowych - odczuwania nadmiernego stresu, wypalenia i frustracji, trudności z panowaniem nad sobą, nadużywania alkoholu i leków, zwiększenia aktywności poprzez nadmierną pracę i/lub wysiłek fizyczny, a także zmian dotychczasowego funkcjonowania zauważanych przez osobę badaną i jej bliskich. Ostatnia pozycja dotyczy występowania $\mathrm{w}$ rodzinie tendencji do odczuwania przy- 
Polish adaptation of the Gotland Scale of Male Depression (GDMS) by Wolfgang Rutz

Polska adaptacja Gotlandzkiej Skali Męskiej Depresji (GDMS) Wolfganga Rutza

scale: from 0 ('completely untrue') to 3 ('mpletely true'). The scale, in its original version, consists of two subscales: the distress scale (items $1,2,5,8,9,10,12$ ) and the depression scale $(3,4,6,7,11,13)$. The overall result is in the range from 0 to 39 points. The authors adopted the following interpretation of the results of the full scale: 0-12 points - no signs of depression; 13-26 - possible depression, appropriate treatment should be considered; 27-39 - depression, most likely treatment is necessary (including pharmacological) [7, 8].

\section{Development of the Polish version of the GDMS scale and statistical analyses}

After obtaining permission from the author for the adaptation of the scale, two translators translated it from English into Polish. Then, two other translators (including a certified court translator) back-translated the scale. After comparing the received versions, the final version was prepared. The reliability and validity of the method were calculated. Reliability was estimated utilizing the Cronbach's a coefficient in different groups of men along with the discriminating power, i.e. the correlation coefficients of the statements and the overall result. The theoretical validity of the scale was verified by the exploratory and confirmatory factor analyses. The exploratory factor analysis (EFA) was used by oblimin rotation to verify the structure of the scale factors, supported the confirmatory factor analysis (CFA) to determine the proper match to the model data obtained in the exploratory analysis. The convergent validity of the method was also estimated through the analysis of correlation coefficients between its results and those of some selected psychometric tools. What is more, the mean results obtained on the scale were compared in a group of healthy men diagnosed with depression and alcohol dependence. Calculations were performed using STATISTICA 10.

\section{The subjects ${ }^{1}$}

The study involved a total of 551 men. They included 400 with neither current nor past diagnosed mental disorders nor serious somatic illnesses. They were the students and postgraduate students of the University of Łodź and the Technical University of Łodź who confirmed, in the survey supplied with the method documentation, that they had never undergone psychiatric treatment or benefited from the help of a psychotherapist (the ones who confirmed the fact of past or current treatment were not taken into account). The men ranged from 18 to 60 years of age $(M=33.41, S D=11.35)$. Sixty men diagnosed with depression were also subjects of the study; the men were treated in the Łódź Clinic of Mental Health

${ }^{1}$ Part of the studies was conducted by Ewa Wieczorek, Paula Rol and Marta Kowalczyk within the framework of their masters' theses. gnębienia lub depresji, podejmowania prób samobójczych i skłonności do niebezpiecznych zachowań. Każde z twierdzeń jest punktowane na 4-stopniowej skali Likerta - od 0 („zupełnie nieprawdziwe”) do 3 („całkowicie prawdziwe"). Skala w wersji oryginalnej składa się z dwóch podskal - dystresu (pozycje 1, 2, 5, 8, 9, 10, 12) i depresji $(3,4,6,7,11,13)$. Wynik ogólny mieści się w przedziale od 0 do 39 pkt. Autorzy przyjęli następujący sposób interpretacji wyników całej skali: 0-12 pkt - brak oznak depresji, 13-26 - możliwa depresja, odpowiednia terapia powinna być brana pod uwagę, 27-39 - depresja, najprawdopodobniej konieczne leczenie (także farmakologiczne) [7, 8].

\section{Opracowanie polskiej wersji skali GDMS i analizy statystyczne}

Po uzyskaniu od autora skali zgody na adaptację dwóch tłumaczy dokonało tłumaczenia $\mathrm{z}$ języka angielskiego na polski. Następnie dwóch innych tłumaczy (w tym tłumacz przysięgły) dokonało tłumaczenia zwrotnego (back translation). Po porównaniu uzyskanych wersji ustalono wersję ostateczną. Obliczono rzetelność i trafność metody. Rzetelność szacowano na podstawie współczynników a Cronbacha w różnych grupach badanych mężczyzn oraz obliczenia mocy dyskryminacyjnej pozycji - współczynników korelacji twierdzeń $\mathrm{z}$ wynikiem ogólnym. Trafność teoretyczną skali weryfikowano poprzez zastosowanie eksploracyjnej i konfirmacyjnej analizy czynnikowej. Eksploracyjną analizę czynnikową (exploratory factor analysis - EFA) metodą rotacji oblimin zastosowano, by zweryfikować strukturę czynników skali, a analizę konfirmacyjną (confirmatory factor analysis - CFA) w celu sprawdzenia stopnia dopasowania do danych modelu uzyskanego w analizie eksploracyjnej. Oszacowano również trafność zbieżną metody przez analizę współczynników korelacji między jej wynikami a wynikami wybranych narzędzi psychometrycznych. Dodatkowo porównano średnie wyniki w skali uzyskane w grupie osób zdrowych, mężczyzn z rozpoznaną depresją oraz uzależnionych od alkoholu. Obliczeń dokonano przy użyciu programu STATISTICA 10.

\section{Osoby badane'}

W badaniach wzięło udział łącznie 551 mężczyzn. Wśród nich u 400 nie występowały obecnie ani w przeszłości zdiagnozowane zaburzenia psychiczne i poważne choroby somatyczne. Byli to studenci oraz słuchacze studiów podyplomowych Uniwersytetu Łódzkiego i Politechniki Łódzkiej, którzy potwierdzili w dołączonej ankiecie, że nigdy nie leczyli się psychiatrycznie ani nie korzystali z pomocy psychoterapeuty (osoby, które potwierdziły fakt przeszłego albo obecnego leczenia nie były brane pod uwagę). Mężczyźni byli w wieku od 18 do 60 lat $(M=33,41, S D=11,35)$. Zbadano również 60

${ }^{1}$ Część badań zostało przeprowadzonych przez Ewę Wieczorek, Paulę Rol oraz Martę Kowalczyk w ramach prac magisterskich. 
(age 24-66 years, $M=44.16, S D=12.00$ ) and 91 alcohol addicts during stationary and outpatient alcoholism treatment programs (age 20-68 years, $M=44.08$, $S D=11.52$ ). The study was anonymous; the patients were informed about its purpose and were allowed to resign at any time.

The following measurement tools were used along with the validated method:

- Beck Depression Inventory - BDI [14] in the Polish adaptation by Parnowski and Jernajczyk [15];

- General Health Questionnaire - GHQ-28 [16] in the Polish adaptation by Makowska and Merecz [17]. The method allows to assess the general state of mental health and its 4 dimensions: somatic symptoms, anxiety and insomnia, social dysfunction and depressive symptoms. The analysis used the subscale for the symptoms of depression;

- Scale of Psychache of Holden et al. [18] in the Polish adaptation by Chodkiewicz et al. [19]. Psychic pain, defined as a strong sense of mental anguish, displays close correlations with both depression and suicidal tendencies [e.g. 20].

The Polish versions of the tools used were characterised by satisfactory indicators of reliability and validity.

\section{RESULTS}

\section{Theoretical accuracy - structure factor validity of the scale}

In order to verify the internal structure of the tool, both the exploratory factor analysis and confirmatory analysis were used. In order to perform necessary calculations, the data from the whole sample of healthy individuals $(N=400)$ was randomly divided into two equal subsets $(n=200)$. The first was subject to the exploratory analysis; the second was subject to the confirmatory one. Before the analyses, the adequacy of selection was verified, using the Kaiser-Meyer-Olkin Measure of Sampling Adequacy. Its value $(\mathrm{KMO}=0.921)$ and the Bartlett test of sphericity $p<0.0001$ indicated that the use of the factor analysis was justified.

\section{Factorial structure of the scale}

The exploratory factor analysis with oblimin rotation and Kaiser normalisation enhanced by the scree test showed that the Polish version of the scale has a two-factor structure, i.e. the first factor with the value of 6.28 explained $47.74 \%$ of the total variance, while the second factor with the value of 1.18 explained $9.10 \%$ of the variance. In total, both factors explained $56.84 \%$ of the total variance. The observed strong 'saturation' of the total variance with factor 1 is shown in Figure I. mężczyzn ze zdiagnozowaną depresją leczących się w łódzkich poradniach zdrowia psychicznego (wiek 24-66 lat, $M=44,16, S D=12,00$ ) oraz 91 uzależnionych od alkoholu odbywających stacjonarną i ambulatoryjną terapię odwykową (wiek 20-68 lat, $M=44,08, S D=11,52$ ). Badanie było anonimowe, pacjenci zostali poinformowani o jego celu i mogli w każdej chwili zrezygnować.

W badaniach, obok walidowanej metody, zastosowano następujące narzędzia pomiaru:

- Inwentarz Depresji Becka (Beck Depression Inventory - BDI) [14] w polskiej adaptacji Parnowskiego i Jernajczyka [15];

- Kwestionariusz Ogólnego Stanu Zdrowia Goldberga (General Health Questionnaire - GHQ-28) [16] w polskiej adaptacji Makowskiej i Merecz [17]. Metoda pozwala ocenić ogólny stan zdrowia psychicznego i jego 4 wymiary: objawy somatyczne, niepokój i bezsenność, zaburzenia funkcjonowania społecznego i objawy depresji. W przeprowadzonej analizie wykorzystano podskalę objawy depresji;

- Skalę Bólu Psychicznego (Scale of Psychache) Holdena i wsp. [18] w polskiej adaptacji Chodkiewicza i wsp. [19]. Ból psychiczny, definiowany jako poczucie silnego psychicznego cierpienia, wykazuje ścisłe związki zarówno $\mathrm{z}$ depresją, jak i tendencjami suicydalnymi [m.in. 20].

Polskie wersje zastosowanych narzędzi charakteryzowały się zadowalającymi wskaźnikami rzetelności i trafności.

\section{WYNIKI}

\section{Trafność teoretyczna - struktura czynnikowa skali}

W celu zweryfikowania struktury wewnętrznej narzędzia wykorzystano zarówno eksploracyjną analizę czynnikową, jak i analizę konfirmacyjną. Aby przeprowadzić niezbędne obliczenia, dane pochodzące z całej próby osób zdrowych $(N=400)$ zostały losowo podzielone na dwa równe podzbiory $(n=200)$. Na pierwszym przeprowadzono analizę eksploracyjną, na drugim konfirmacyjną. Przed rozpoczęciem analiz sprawdzono dokładność doboru przy użyciu testu Kaisera-Mayera-Olkina (Kaiser-Meyer-Olkin Measure of Sampling Adequacy). Jego wartość $(\mathrm{KMO}=0,921)$ oraz wskaźnik sferyczności Bartletta (Bartlett test of sphericity) $p<0,0001$ wskazywały, że zastosowanie analizy czynnikowej jest uprawnione.

\section{Struktura czynnikowa skali}

Zastosowana eksploracyjna analiza czynnikowa, metoda rotacji oblimin z normalizacją Kaisera oraz test osypiska wykazały, że polska wersja skali ma strukturę dwuczynnikową - czynnik pierwszy o wartości własnej 6,28 wyjaśniał $47,74 \%$, a czynnik drugi o wartości własnej 1,18 wyjaśniał 9,10\% wariancji ogólnej. Łącznie obydwa czynniki wyjaśniały 56,84\% wariancji ogólnej. Zaobserwowane, silne „wysycenie" wariancji ogólnej przez czynnik 1 obrazuje rycina I. 
Polish adaptation of the Gotland Scale of Male Depression (GDMS) by Wolfgang Rutz

Polska adaptacja Gotlandzkiej Skali Męskiej Depresji (GDMS) Wolfganga Rutza

\section{Components in the rotated solution/Wykres składowych w rozwiqzaniu rotowanym}

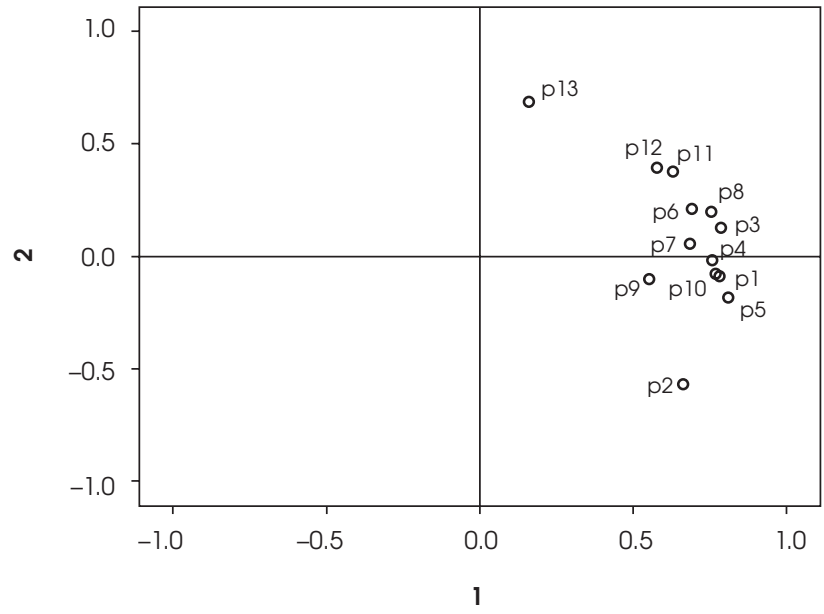

Figure I. Gotland Male Depression Scale (GDMS) factors extracted

Rycina I. Wyodrębnione czynniki Gotlandzkiej Skali Męskiej Depresji (GDMS)

Source: own study/Źródło: opracowanie własne.

Analysing Figure I, it can be seen that all of the items positively charge factor (component) one; the nature of this factor is best seen in items 1, 5 and 10 (the ones most to the right in the figure). In turn, the second factor positively charges items $13,11,12$ to the greatest extent. However, if the criterion of 0.5 charge belonging to the scale is assumed, it turns out that almost all of the test items meet the criteria for component 1 (above 0.5 in this dimension and below 0.5 for component 2), while only item 13 belongs to component 2 . This analysis supports the one-factor structure of the scale.

The confirmatory analysis carried out in the second drawn group of the subjects showed that the two-factor solution with the original structure of items in each factor is unsatisfactorily matched to the data: $\chi^{2}=106.56$, $d f=65, p=0.0008 ; \mathrm{RMSEA}=0.11 ; \mathrm{GFI}=0.77$; $\mathrm{AGFI}=0.68$. Subsequently, it was decided to test the one-factor solution. The solution turned out to be satisfactorily matched to the data: $\chi^{2}=74.99, d f=65, p=0.18$; RMSEA $=0.051$; $\mathrm{GFI}=0.912, \mathrm{AGFI}=0.880, \mathrm{CFI}=0.896$. This confirms the conclusion that the one-factor structure is more suited to the Polish version of the scale. The CFA results are presented in Table 1.

\section{Reliability}

The reliability of the tool was calculated by estimating the internal consistency and calculating the discriminating power of the items. The internal consistency, evaluated utilizing the Cronbach's $\alpha$, was 0.85 for the GDMS in the healthy control group, 0.88 in the group with alcohol dependence and 0.87 in the group of the men with depres-
Analizując rycinę I, można zaobserwować, że wszystkie itemy ładują dodatnio czynnik (składową) pierwszy; naturę tego czynnika najbardziej oddają (są najbardziej przesunięte na prawo) pozycje 1, 5 i 10. Z kolei czynnik drugi najsilniej dodatnio ładują itemy 13, 11 i 12. Jeśli jednak przyjąć za kryterium przynależności do skali 0,5 ładunku, okazuje się, że prawie wszystkie pozycje testowe spełniają kryteria składowej 1 . (powyżej 0,5 na tym wymiarze i poniżej 0,5 na 2. składowej), natomiast do składowej 2. należy jedynie pozycja numer 13. Analiza ta przemawia za przyjęciem jednoczynnikowej struktury skali.

Również analiza konfirmacyjna przeprowadzona na drugiej grupie osób badanych wykazała, że rozwiązanie dwuczynnikowe z oryginalną strukturą itemów w każdym czynniku jest niezadawalająco dopasowane do danych: $\chi^{2}=106,56, d f=65, p=0,0008$; RMSEA = 0,11; GFI = 0,77; $\mathrm{AGFI}=0,68$. W dalszej kolejności postanowiono więc przetestować rozwiązanie jednoczynnikowe. Rozwiązanie to okazało się zadawalająco dopasowane do danych: $\chi^{2}=74,99, d f=65, p=0,18 ; \operatorname{RMSEA}=0,051 ; \mathrm{GFI}=0,912$, AGFI $=0,880$, CFI $=0,896$. Potwierdza to wniosek, że struktura jednoczynnikowa bardziej odpowiada polskiej wersji skali. Wyniki CFA przedstawia tabela 1.

\section{Rzetelność}

Rzetelność narzędzia obliczono poprzez oszacowanie zgodności wewnętrznej oraz obliczenie mocy dyskryminacyjnej pytań. Zgodność wewnętrzna, oceniona na podstawie a Cronbacha, wynosiła dla skali GDMS 0,85 w grupie osób zdrowych, 0,88 w grupie uzależnionych od alkoholu i 0,87 w grupie mężczyzn z depresją. Ponieważ 
Table 1. Results of the CFA parameter of the Gotland Male Depression Scale (GDMS)

Tabela 1. Wyniki parametru CFA w Gotlandzkiej Skali Męskiej Depresji (GDMS)

\begin{tabular}{|c|c|}
\hline $\begin{array}{c}\text { Items/ } \\
\text { Pozycje }\end{array}$ & $\begin{array}{c}\text { CFA parameter estimate/ } \\
\text { CFA - ocena parametru }\end{array}$ \\
\hline 1 & $0.603^{* *}$ \\
\hline 2 & $0.665^{* *}$ \\
\hline 3 & $0.842^{* *}$ \\
\hline 4 & $0.679^{* *}$ \\
\hline 5 & $0.805^{* *}$ \\
\hline 6 & $0.739^{* *}$ \\
\hline 7 & $0.726^{* *}$ \\
\hline 8 & $0.770^{* *}$ \\
\hline 9 & $0.593^{* *}$ \\
\hline 10 & $0.796^{* *}$ \\
\hline 11 & $0.487^{* *}$ \\
\hline 12 & $0.755^{* *}$ \\
\hline 13 & $0.366^{*}$ \\
\hline
\end{tabular}

Source: own study/Źródło: opracowanie własne.

${ }^{*}$ Significant path $p<0.001,{ }^{* *}$ significant paths $p<0.0001 /$

*Ścieżka istotna $p<0,001$, **́cieżki istotne $p<0,0001$

sion. Since the coefficients obtained exceeded the recommended value of 0.7 , it can be said that the method is characterised by a fully satisfactory reliability.

The next step was to analyse the discriminating power of the questionnaire items. The results for the whole group of the healthy subjects $(N=400)$ are presented in Table 2.

The data in Table 2 indicates that the Cronbach's a coefficient does not increase after the removal of any of the items. The discriminating power of the analysed items of the scale is satisfactory: the correlation of the items with the overall result was (except for statement 13) from 0.43 for item $11(p<0.001)$ to 0.72 for item $3(p<0.001)$. The weakest correlation $(0.31)$ was observed in item 13. It should be noted that item 13 was also the only item in the confirmatory analysis, in which the factor charge was below 0.4 (and therefore this item has less than $16 \%$ of the variance common with the overall result) (cf. Table 1).

\section{External validity}

The external validity of the adapted method was based on the analysis of the correlation between its results and those obtained using the Beck Depression Inventory, GHQ-28 Scale (depression subscale) and the Scale of Psychache. The results of the correlation (Pearson $r$ ) are presented in Table 3. The comparison was made in the group of healthy subjects and those diagnosed with depression.

As indicated in Table 3, the validated method is characterised by a satisfactory external validity. Signifi- otrzymane współczynniki przekraczały rekomendowaną wartość 0,7 , można stwierdzić, że metoda charakteryzuje się w pełni satysfakcjonującą rzetelnością.

Kolejnym krokiem była analiza mocy dyskryminacyjnej pozycji kwestionariusza. Wyniki dla całej grupy osób zdrowych $(N=400)$ przedstawia tabela 2.

Dane zawarte w tabeli 2 wskazują, że współczynnik a Cronbacha nie wzrasta po usunięciu żadnej pozycji. Moc dyskryminacyjna analizowanych pozycji skali jest zadowalająca: korelacja twierdzeń $\mathrm{z}$ wynikiem ogólnym wyniosła (poza twierdzeniem 13.) od 0,43 dla pozycji 11 $(p<0,001)$ do 0,72 dla pozycji $3(p<0,001)$. Najsłabszy związek $(0,31)$ zaobserwowano w odniesieniu do pozycji 13. Warto zauważyć, że pozycja 13 była jednocześnie jedyną pozycją w analizie konfirmacyjnej, w której ładunek czynnikowy wynosił poniżej 0,4 (a więc pozycja ta ma mniej niż 16\% wspólnej wariancji z wynikiem ogólnym) (por. tabela 1).

\section{Trafność zewnętrzna}

Trafność zewnętrzną adaptowanej metody oszacowano na podstawie analizy związków między jej wynikami a wynikami uzyskanymi za pomocą Skali Depresji Becka, Skali GHQ-28 (podskala objawy depresji) oraz Skali Bólu Psychicznego. Wyniki korelacji ( $r$ Pearsona) przedstawia tabela 3. Porównania dokonano w grupie osób zdrowych oraz z rozpoznaną depresją.

Jak wskazuje tabela 3, walidowana metoda charakteryzuje się zadowalającą trafnością zewnętrzną. Otrzyma- 
Polish adaptation of the Gotland Scale of Male Depression (GDMS) by Wolfgang Rutz

Polska adaptacja Gotlandzkiej Skali Męskiej Depresji (GDMS) Wolfganga Rutza

Table 2. Discriminant power of the Gotland Male Depression Scale (GDMS) items Tabela 2. Moc dyskryminacyjna pozycji w Gotlandzkiej Skali Męskiej Depresji (GDMS)

\begin{tabular}{|c|c|c|}
\hline Number of position/Numer pozycji & $\begin{array}{l}\text { Discriminant power } \\
\text { coefficients/ } \\
\text { Współczynniki mocy } \\
\text { dyskryminacyjnej }\end{array}$ & $\begin{array}{l}\alpha \text { with the item } \\
\text { deleted/ } \\
\alpha \text { - gdy pozycja } \\
\text { usunięta }\end{array}$ \\
\hline $\begin{array}{l}\text { 1. Lower stress threshold/more stressed out than usual/ } \\
\text { Byłem bardziej zestresowany niż zwykle, miałem niższy próg odporności na stres }\end{array}$ & 0.49 & 0.84 \\
\hline $\begin{array}{l}\text { 2. More aggressive, outward-reacting, difficulties keeping self-control/ } \\
\text { Byłem bardziej agresywny, miałem trudności w panowaniu nad sobą }\end{array}$ & 0.54 & 0.83 \\
\hline 3. Feeling of being burned out and empty/Czułem się wypalony i pusty & 0.72 & 0.82 \\
\hline 4. Constant, inexplicable tiredness/Byłem ciągle niewytłumaczalnie zmęczony & 0.49 & 0.83 \\
\hline $\begin{array}{l}\text { 5. More irritable, restless and frustrated/ } \\
\text { Byłem bardziej rozdrażniony, niespokojny, sfrustrowany }\end{array}$ & 0.64 & 0.82 \\
\hline $\begin{array}{l}\text { 6. Difficulty making ordinary everyday decisions/ } \\
\text { Miałem trudności w podejmowaniu zwykłych, codziennych decyzji }\end{array}$ & 0.49 & 0.84 \\
\hline $\begin{array}{l}\text { 7. Sleep problems: sleeping too much/too little/restlessly, difficulty falling asleep/ } \\
\text { waking up early/ } \\
\text { Miałem problemy ze snem: spałem za dużo/za mało/niespokojnie, miałem trudności } \\
\text { z zasypianiem/wcześnie się budziłem }\end{array}$ & 0.59 & 0.83 \\
\hline $\begin{array}{l}\text { 8. In the morning especially, having a feeling of disquiet/ anxiety/uneasiness/ } \\
\text { Szczególnie rano miałem uczucie lęku, niepokoju, trwogi }\end{array}$ & 0.60 & 0.83 \\
\hline $\begin{array}{l}\text { 9. Overconsumption of alcohol and pills in order to achieve a calming and relaxing } \\
\text { effect. Being hyperactive or blowing off steam by working hard and restlessly, } \\
\text { jogging or other exercises, under- or overeating/ } \\
\text { Spożywałem nadmierną ilość alkoholu lub leków, by się uspokoić, zrelaksować. } \\
\text { Wyżywałem się, ciężko pracując, dużo ćwicząc (bieganie, siłownia), przejadałem się } \\
\text { lub mało jadłem }\end{array}$ & 0.47 & 0.83 \\
\hline $\begin{array}{l}\text { 10. Do you feel your behaviour has altered in such a way that neither can you or others } \\
\text { recognise yourself or that you are difficult to deal with?/ } \\
\text { Czy sądzi Pan, że Pana zachowanie zmieniło się w taki sposób, że ani Pan, ani inni } \\
\text { nie poznają Pana i trudno jest im z Panem wytrzymać? }\end{array}$ & 0.63 & 0.83 \\
\hline $\begin{array}{l}\text { 11. Have you felt or have others perceived you as being gloomy, negative or } \\
\text { characterised by a state of hopelessness, in which everything looks bleak?/ } \\
\text { Czy czuje Pan, że inni spostrzegają Pana jako ponurego, pełnego negatywizmu } \\
\text { lub będącego w złym stanie? }\end{array}$ & 0.43 & 0.84 \\
\hline $\begin{array}{l}\text { 12. Have you or others noticed that you have a greater tendency to self-pity, } \\
\text { to be complaining or to seem 'pathetic'?/ } \\
\text { Czy Pan lub inni stwierdziliście, że ma Pan tendencję do większego użalania się } \\
\text { nad sobą, skarżenia się lub bycia godnym współczucia? }\end{array}$ & 0.57 & 0.83 \\
\hline $\begin{array}{l}\text { 13. In your biological family, is there any tendency towards abuse, depression/ } \\
\text { dejection, suicide attempts or proneness to behaviour involving danger/ } \\
\text { Czy w Pana rodzinie pochodzenia istnieje (istniała) tendencja do uzależnień, depresji/ } \\
\text { przygnębienia, prób samobójczych lub skłonność do niebezpiecznych zachowań? }\end{array}$ & 0.31 & 0.85 \\
\hline
\end{tabular}

Source: own study/Źródło: opracowanie własne.

cant correlation coefficients (at the level of $p<0.01$ and $p<0.001$ ) were obtained between the GDMS and the methods for examining depression and psychache. Noteworthy is the fact that stronger correlations between the variables were observed in patients diagnosed with depression, as compared to the healthy subjects.

\section{Normalization}

At the last stage, comparison was performed for the results obtained in the GDMS in three groups of men healthy, addicted to alcohol and treated for depression. The results of the applied analysis of variance are presented in Table 4. no istotne (na poziomie $p<0,01$ i $p<0,001$ ) współczynniki korelacji między GDMS a metodami badającymi depresję i ból psychiczny. Na uwagę zasługuje fakt, że silniejsze związki między zmiennymi zaobserwowano $\mathrm{w}$ grupie osób $\mathrm{z}$ rozpoznaną depresją w porównaniu z osobami zdrowymi.

\section{Normalizacja}

$\mathrm{Na}$ ostatnim etapie dokonano porównania wyników uzyskanych w Skali GDMS w trzech grupach mężczyzn - zdrowych, uzależnionych od alkoholu i leczących się z powodu depresji. Wyniki zastosowanej analizy wariancji przedstawia tabela 4 . 
Table 3. Correlation coefficients of the Gotland Male Depression Scale (GDMS) and the results of the Beck Depression Inventory (BDI), General Health Questionnaire, subscale - symptoms of depression (GHQ-28), Scale of Psychache - the healthy $(n=400)$ and the people with depression diagnosed $(n=60)$

Tabela 3. Współczynniki korelacji Gotlandzkiej Skali Męskiej Depresji (GDMS) z wynikami Inwentarza Depresji Becka (BDI), Kwestionariusza Ogólnego Stanu Zdrowia Goldberga, podskala - objawy depresji (GHQ-28), Skali Bólu Psychicznego - osoby zdrowe $(n=400)$ i z rozpoznanq depresją $(n=60)$

\begin{tabular}{|l|l|}
\hline BDI, the healthy/BDI - zdrowi & GDMS \\
\hline BDI, people with depression diagnosed/BDI - osoby z rozpoznana depresja & $0.84^{* * *}$ \\
\hline GHQ-28 - symptoms of depression, the healthy/GHQ-28 - objawy depresji, zdrowi & $0.58^{* * *}$ \\
\hline GHQ-28 - symptoms of depression, those diagnosed with depression/GHQ-28 - objawy depresji, osoby z rozpoznanq depresją & $0.77^{* * *}$ \\
\hline Scale of Psychache - the healthy/Skala Bólu Psychicznego - zdrowi & $0.34^{* *}$ \\
\hline Scale of Psychache - the people with depression diagnosed/Skala Bólu Psychicznego - osoby z rozpoznanq depresją & $0.42^{* *}$ \\
\hline
\end{tabular}

Source: own study Źródło: opracowanie własne.

Significant correlation ${ }^{* *} p<0.01,{ }^{* * *} p<0.001 /$ Korelacja istotna ${ }^{* *} p<0,01,{ }^{* * *} p<0,001$

Table 4. Comparison of the Gotland Male Depression Scale (GDMS) means scores in the study groups Tabela 4. Porównanie średnich wyników w Gotlandzkiej Skali Męskiej Depresji (GDMS) w badanych grupach

\begin{tabular}{|c|c|c|c|c|c|c|c|c|}
\hline \multirow[t]{2}{*}{$\begin{array}{c}\text { Tool/ } \\
\text { Narzędzie }\end{array}$} & \multicolumn{2}{|c|}{$\begin{array}{l}\text { 1. Healthy men/ } \\
\text { Mężczyźni zdrowi } \\
\quad n=400\end{array}$} & \multicolumn{2}{|c|}{$\begin{array}{l}\text { 2. Men addicted to alcohol/ } \\
\text { Mężczyźni uzależnieni od alkoholu } \\
\qquad n=91\end{array}$} & \multicolumn{2}{|c|}{$\begin{array}{l}\text { 3. Men diagnosed with depression/ } \\
\text { Mężczyźni z rozpoznanq̨ depresją } \\
\qquad n=60\end{array}$} & \multirow[t]{2}{*}{$F$} & \multirow[t]{2}{*}{$p$} \\
\hline & $M$ & $S D$ & $M$ & $S D$ & $M$ & $S D$ & & \\
\hline GDMS & 6.26 & 5.71 & 13.00 & 6.48 & 20.67 & 7.03 & 99.04 & $0.001^{a, b, c}$ \\
\hline
\end{tabular}

Source: own study/Źródło: opracowanie własne.

Tukey post-hoc test, a differences between groups 1 and $2, p<0.001 ;{ }^{b}$ differences between groups 1 and $3, p<0.001 ;{ }^{c}$ differences between groups 2 and 3 , $p<0.001 /$ Test post-hoc Tukeya: aróżnice między grupq 1 i 2, $p<0,001$, bróżnice między grupq 7 i 3, p<0,001; cróżnice między grupq 2 i 3, p<0,001

As shown in Table 4, statistically significant differences were observed between all of the analysed groups; the healthy men obtained the lowest scores, and those with depression diagnosed - the highest. At the same time, the men dependent on alcohol obtained significantly higher results than the healthy subjects and lower than those with depression diagnosed (all differences $p<0.001)$.

It was also decided to see what percentage of the men surveyed in all groups meets the criteria for possible depression (score over 13 points, according to the instructions) and depression (score over 27 points). In the group of healthy subjects, $13 \%$ of the respondents scored over 13 points, $42 \%$ in the group of alcoholics and $79 \%$ in the group of the patients with depression. The result strongly supporting the occurrence of depression was scored by $2 \%$ of the healthy subjects, $5 \%$ of alcoholics and $28 \%$ of the depressive patients. All of the obtained results indicate that the GDMS well discriminates the studied groups of subjects.

\section{DISCUSSION OF RESULTS AND CONCLUSIONS}

The aim of this study was to validate the Polish version of the screening test for the needs of the study of the intensity of the atypical symptoms of depression, as created by
Jak pokazuje tabela 4 odnotowano istotne statystycznie różnice między wszystkimi analizowanymi grupami - mężczyźni zdrowi uzyskali wyniki najniższe, a ci z rozpoznaną depresją najwyższe. Jednocześnie mężczyźni uzależnieni do alkoholu uzyskali wyniki istotnie wyższe w porównaniu ze zdrowymi, a niższe w porównaniu $\mathrm{z}$ tymi $\mathrm{z}$ rozpoznaną depresją (wszystkie różnice $p<0,001$ ).

Postanowiono również sprawdzić, jaki procent spośród badanych mężczyzn we wszystkich grupach spełnia kryteria możliwej depresji (wynik powyżej 13 pkt, zgodnie $z$ instrukcją) oraz depresji (wynik powyżej 27 pkt). W grupie osób zdrowych wynik powyżej 13 pkt uzyskało $13 \%$ badanych, w grupie alkoholików - 42\%, a w grupie pacjentów z depresją 79\%. Wynik zdecydowanie przemawiający za występowaniem depresji uzyskało odpowiednio $2 \%$ osób zdrowych, $5 \%$ alkoholików i $28 \%$ pacjentów depresyjnych. Całość uzyskanych wyników wskazuje, że skala GDMS dobrze dyskryminuje badane grupy osób.

\section{OMÓWIENIE WYNIKÓW I WNIOSKI}

Celem prezentowanego badania była walidacja polskiej wersji przesiewowego testu do badania natężenia atypowych objawów depresji stworzonego przez W. Rutza [7, 8]. Zastosowana eksploracyjna i konformacyjna analiza czynnikowa wskazuje, że polska wersja metody charakteryzuje się strukturą jednoczynnikową. Podobne wnioski uzyskano, 
Polish adaptation of the Gotland Scale of Male Depression (GDMS) by Wolfgang Rutz

Polska adaptacja Gotlandzkiej Skali Męskiej Depresji (GDMS) Wolfganga Rutza

W. Rutz $[7,8]$. The exploratory and conformational factor analyses used indicate that the Polish version of the method is characterised by a one-factor structure. Similar conclusions were obtained during adaptation of the tool in Italy; the Italian version also presented a one-factor structure, and item 13 showed the weakest correlations with the general factor [13]. The two-factor structure of the scale was not confirmed in the Chinese studies, either, in which the analogous item 13 showed the weakest correlations with the general factor, but the correlation coefficient was higher there than the one in the Polish version (0.50, in the Polish version it was 0.31 ) [12]. It seems that the existence of the last item of the scale, concerning the prevalence of depressive disorders among family members, requires further analysis and/or any consideration of the removal of it. The information on the disorders in the family of origin is undoubtedly important diagnostically and therapeutically; however, it applies to a different subject area than the currently occurring depressive symptoms. In addition, patients may have incomplete knowledge on the disorders or may not want to disclose them.

The Cronbach's a (0.85-0.88) coefficient obtained indicate a fully satisfactory reliability of the Polish version of the tool. Similar coefficients were obtained in the Italian $(\alpha=0.87)$, Chinese $(\alpha=0.93)$ and German $(\alpha=0.81)$ studies and in the validation study carried out with the participation of people with alcohol dependence $(\alpha=0.86)$ [9, $10,12,13]$.

The adapted method shows a strong correlation with other methods for the diagnosis of depression (BDI, GHQ 28 - depression subscale), confirming its satisfactory validity. Similar results were demonstrated in other studies; for example, the GDMS correlation coefficient with Beck BDI was 0.83 in the Chinese, 0.80 in the Swedish and 0.73 in the Icelandic studies $[11,12,21]$. Other studies used other comparative tools, for example, the Beck Hopelessness Scale (BHS), also showing significant correlations [among others 13].

The GDMS mean results differed significantly in the case of the healthy men, men with alcohol dependence and those diagnosed with depression. The Icelandic studies on healthy men $(n=534)$ showed that they obtained the GDMS mean result equal to 4.1 points, which was only slightly lower than in the test group (6.24) [11]. At the same time, $14 \%$ obtained the result indicating possible depression, which is in line with the present study - $13 \%$ of such men. A different result was obtained in Germany during a study on a large group of young men (mean age 18.5 years, $n=1004$ ), where $22 \%$ obtained results over 13 points of the GDMS [9]. This difference may be due to the increased impulsivity and tendency to risky behaviour and mood swings among young men, as compared with the elderly ones. In turn, the studies of Zierau et al. [10] showed that $39 \%$ of the men with alcohol dependence $(n=87)$ meet the criteria for a possible depression. It is worth noting that a similar result (42\%) was przeprowadzając adaptację narzędzia we Włoszech - wersja włoska również prezentowała strukturę jednoczynnikową, a pozycja 13. wykazywała najsłabsze związki z czynnikiem ogólnym [13]. Dwuczynnikowej struktury skali nie potwierdzono także w badaniach chińskich, w których analogicznie pozycja 13. wykazywała najsłabsze związki z czynnikiem ogólnym, jednakże współczynnik korelacji był tam wyższy niż w wersji polskiej $(0,50$, w wersji polskiej 0,31) [12]. Wydaje się więc, że istnienie ostatniej pozycji skali, dotyczącej występowania zaburzeń depresyjnych wśród członków rodziny, wymaga dalszej analizy i/lub ewentualnego rozpatrzenia jej usunięcia. Informacja o zaburzeniach w rodzinie pochodzenia, choć niewątpliwie istotna diagnostycznie i terapeutycznie, dotyczy jednak innego obszaru tematycznego niż aktualnie występujące objawy depresyjne. Ponadto pacjenci mogą mieć na temat tych zaburzeń wiedzę niepełną, mogą też nie chcieć ich ujawniać.

Otrzymane współczynniki a Cronbacha $(0,85-0,88)$ wskazują na w pełni zadawalającą rzetelność polskiej wersji narzędzia. Zbliżone współczynniki otrzymano w badaniach włoskich $(\alpha=0,87)$, chińskich $(\alpha=0,93)$, niemieckich ( $\alpha=$ 0,81 ) oraz w badaniu walidacyjnym prowadzonym na osobach uzależnionych od alkoholu $(\alpha=0,86)[9,10,12,13]$.

Adaptowana metoda wykazuje silnie związki z innymi metodami badającymi depresję (BDI, GHQ-28 - podskala depresji), co potwierdza jej satysfakcjonującą trafność. Podobne zależności wykazano w innych badaniach, np. współczynnik korelacji skali GDMS ze skalą Becka wyniósł $0,83 \mathrm{w}$ badaniach chińskich, $0,80 \mathrm{w}$ badaniach szwedzkich i $0,73 \mathrm{w}$ badaniach islandzkich $[11,12,21]$. W pozostałych badaniach stosowano inne narzędzia porównawcze, np. Skalę Beznadziejności Becka (Beck Hopelessness Scale - BHS), również wykazując istotne zależności [m.in. 13].

Średnie wyników skali GDMS istotnie różniły się u mężczyzn zdrowych, uzależnionych od alkoholu i z rozpoznaną depresją. Badania przeprowadzone na Islandii na zdrowych mężczyznach ( $n=534)$ wykazały, że uzyskali oni średnią w skali GDMS równą 4,1 pkt, co jest wynikiem tylko nieco niższym niż w badanej grupie $(6,24)$ [11]. Jednocześnie w tych badaniach $14 \%$ uzyskało wynik wskazujący na możliwą depresję, co jest zgodne z przedstawionym badaniem, gdzie takich mężczyzn było 13\%. Odmienny wynik uzyskano w Niemczech, badając dużą grupę młodych mężczyzn (średnia wieku 18,5 roku, $n=1004$ ), gdzie odnotowano 22\% osób, które uzyskały powyżej 13 pkt w skali GDMS [9]. Różnica ta może wynikać z większej impulsywności oraz skłonności do zachowań ryzykownych i wahań nastroju u młodych mężczyzn w porównaniu ze starszymi. Z kolei badania Zierau i wsp. [10] wykazały, że wśród mężczyzn uzależnionych od alkoholu ( $n=87$ ) 39\% spełnia kryteria możliwej depresji. Warto zwrócić uwagę, że na podobnej próbie w prezentowanych badaniach u uzależnionych mężczyzn otrzymano zbliżony wynik (42\%).

Porównując wyniki uzyskane w badaniach przeprowadzonych wśród leczących się mężczyzn z zaburzeniami 
obtained with a similar sample in the present study for the addicted men.

Comparing the results obtained in the studies conducted among the treated men with depressive disorders, it can be seen that they obtained the mean GDMS scores in the range from 16.10 to $17.8[11,13]$. It also turned out that between 17.04 and $22.9 \%$ of such patients [11, $22,23]$ exhibit results supporting the current prevalence of depression (over 26 points). Thus, the results are somewhat lower (20.67 in the present study) both with respect to the mean and to the percentage of persons obtaining a score greater than 26 points on the scale $(28 \%)$. This discrepancy may be due, inter alia, to the heterogeneity of the persons with depression, the small size of the Polish sample and the fact that these patients may be at different stages of the treatment of depressive disorders. The issue of the intensity of the atypical symptoms among men treated for depression therefore requires further, indepth analyses. Future studies should also verify the correlation between the GDMS and suicidal tendencies as there is data indicating that the results of the scale can be a sensitive predictor of the trends $[13,22]$.

The present study has its limitations. First of all, the basic validation calculations were performed on healthy men, and they would need to be performed in the group of men with depression, too, as in the Italian or Chinese studies $[12,13]$. What is more, only men were subject to the studies, while some data indicates no differences on the scale between men and women [13, 24]. According to Möller-Leimkühler and Yücel [24], it may be due to the more contemporary social acceptance of risky and aggressive behaviour represented by women, particularly exposed to chronic stressors. Is it possible that we are not dealing with male depression, but with depression with a clinical picture different than the typical, regardless of gender? The answer to this question should be given in future studies on large groups of both women and men. Further studies should also take into account other tools for the study of male depression, such as the Male Depression Risk Scale (MDRS-22) by Rice et al. [25] and the Masculine Depression Scale (MDS) by Magovcevic and Addis [26].

In conclusion, despite the above-mentioned concerns, it can be stated that the Polish version of the GDMS has fully satisfactory psychometric properties. The method can be recommended for use both in research and screening studies. In the latter case, it seems desirable to draw attention both to the total score as well as to the analysis of the responses to the items. The items, e.g. on the use of psychoactive substances, may provide a starting point for carrying out further, in-depth diagnostics. In contrast, calculating and analysing the two subscales suggested in the original scale - distress and depression - seems to be of little use. The method is short, understandable and easy to use, so it can help in isolating persons who may experience depression and related suicidal tendencies. depresyjnymi, można zauważyć, że uzyskiwali oni średnie wyniki w GDMS w przedziale od 16,10 do 17,8 [11, 13]. Okazało się też, że wśród takich pacjentów wyniki przemawiające za aktualnym występowaniem depresji (powyżej 26 pkt) wykazuje między 17,04 a 22,9\% badanych [11, 22, 23]. Wyniki te są więc nieco niższe zarówno w przypadku średnich (20,67 w obecnym badaniu), jak i w odniesieniu do odsetka osób uzyskujących wynik powyżej $26 \mathrm{pkt}$ w skali (28\%). Rozbieżność ta może wynikać m.in. z heterogeniczności osób chorych na depresję, niewielkiej liczebności grupy polskiej oraz faktu, że badani pacjenci mogą być na różnym etapie leczenia zaburzeń depresyjnych. Problem dotyczący natężenia atypowych objawów wśród mężczyzn leczących się na depresję wymaga więc dalszych, pogłębionych analiz. W przyszłych badaniach warto również sprawdzić relacje między GDMS a tendencjami suicydalnymi, gdyż istnieją dane wskazujące, że wyniki w skali mogą być czułym predyktorem tych tendencji [13, 22].

Prezentowane badania mają swoje ograniczenia. Przede wszystkim podstawowe obliczenia walidacyjne zostały wykonane na zdrowych mężczyznach, a należałoby je wykonać także na grupie mężczyzn $\mathrm{z}$ depresją, podobnie jak w badaniach włoskich czy chińskich $[12,13]$. Ponadto, badaniom poddano wyłącznie mężczyzn, podczas gdy niektóre dane wskazują na brak różnic między kobietami i mężczyznami w obrębie skali [13, 24]. Zdaniem Möller-Leimkühler i Yücel [24] może to wynikać z większej współcześnie akceptacji społecznej dla zachowań ryzykownych i agresywnych dokonywanych przez kobiety, zwłaszcza narażonych na działanie przewlekłych stresorów. Być może więc mamy do czynienia nie tyle z męską depresją, ale z depresją o odmiennym od typowego obrazie klinicznym występującą niezależnie od płci? Odpowiedź na to pytanie powinny dać przyszłe badania na dużych grupach klinicznych zarówno kobiet, jak i mężczyzn. W dalszych badaniach warto również uwzględnić inne narzędzia służące do badania męskiej depresji, takie jak Male Depression Risk Scale (MDRS-22) autorstwa Rice i wsp. [25] oraz Masculine Depression Scale (MDS) Magovcevic i Addisa [26].

Podsumowując, pomimo powyższych wątpliwości, można stwierdzić, że polska wersja skali GDMS charakteryzuje się w pełni zadawalającymi właściwościami psychometrycznymi. Metodę można polecać zarówno do stosowania w analizach naukowych, jak i w badaniach przesiewowych. W tym ostatnim przypadku wskazane wydaje się zwrócenie uwagi zarówno na wynik sumaryczny, jak i na analizę odpowiedzi na poszczególne pytania. Pytania te, np. dotyczące używania substancji psychoaktywnych, mogą stanowić punkt wyjścia do prowadzenia dalszej, pogłębionej diagnostyki. Natomiast obliczanie i analizowanie zasugerowanych w oryginalnej skali dwóch podskal - dystresu i depresji - wydaje się mało przydatne. Skala jest krótka, zrozumiała i łatwa do wykorzystania, może więc pomóc $w$ wyodrębnianiu osób mogących doświadczać depresji oraz związanych z nią tendencji samobójczych. 
Polish adaptation of the Gotland Scale of Male Depression (GDMS) by Wolfgang Rutz

Polska adaptacja Gotlandzkiej Skali Męskiej Depresji (GDMS) Wolfganga Rutza

\section{Conflict of interest/Konflikt interesu}

Absent./Nie występuje.

\section{Financial support/Finansowanie}

Absent./Nie występuje.

\section{References/Piśmiennicłwo}

1. Centers for Disease Control and Prevention: Suicide: Facts at a Glance. Available from: http://www.cdc.gov/ violenceprevention/pdf/Suicide-DataSheet-a.pdf [Accessed 20 December 2015].

2. Nolen-Hoeksema S. Gender differences in depression. Curr Dir Psychol 2001; 10: 173-176.

3. Rutz W, Rihmer Z. Suicidality in men - practical issues, challenges, solutions. J Mens Health Gend 2007; 4: 393-401.

4. Sher L. Suicide in men. J Clin Psychiatry 2015; 76: 371-372.

5. Walinder J, Rutz W. Male depression and suicide. Int Clin Psychopharmacol 2001; 16: 21-24.

6. Rutz W, Walinder J, Von Knorring L, Rihmer Z, Pihlgren H. Prevention of depression and suicide by education and medication: impact on male suicidality. An update from the Gotland study. Int J Psychiatry Clin Pract 1997; 1: 39-46.

7. Rutz W. Improvement of care for people suffering from depression: the need for comprehensive education. Int Clin Psychopharmacol 1999; 14: 27-33.

8. Rutz W, von Knorring L, Pihlgren H, Rihmer Z, Walinder J. An educational project on depression and its consequences: is the frequency of major depression among Swedish men underrated, resulting in high suicidality? Primary Care Psychiatry 1995; 1: 59-63.

9. Möller-Leimkühler AM. "Male depression" in einer Bevölkerungsstichprobe junger Männer. Risiko und Symptome. Der Nervenarzt 2007; 78: 641-650.

10. Zierau F, Bille A, Rutz W, Bech P. The Gotland Male Depression Scale: a validity study in patients with alcohol use disorder. Nordic J Psychiatry 2002; 56: 265-271.

11. Sigurdsson B, Palsson SP, Aevarsson O, Olafsdottir M, Johannsson M. Validity of Gotland Male Depression Scale for male depression in a community study: The Sudurnesjamenn study. J Affect Disord 2015; 173: 81-89.

12. Chu CL, Chen Y, Jiang KH, Chen JL, Lee CP, Chau YL, et al. Validity and clinical utilization of the Chinese version of the Gotland Male Depression Scale at a men's health polyclinic. Neuropsychiatric Dis Treat 2014; 10: 1707-1714.

13. Innamorati M, Pompili M, Gonda X, Amore M, Serafini G, Niolu C, et al. Psychometric properties of the Gotland Scale for Depression in Italian psychiatric inpatients and its utility in the prediction of suicide risk. J Affect Disord 2011; 133: 99-103.

14. Beck A, Steer R. Manual for the Beck Depression Inventory. San Antonio: Psychological Corporation; 1987.

15. Parnowski T, Jernajczyk W. Inwentarz Depresji Becka w ocenie nastroju osób zdrowych i chorych na choroby afektywne [Beck's Depression Inventory in the rating of mood in normal subjects and in patients with affective disturbances]. Psychiatr Pol 1977; 11: 417-442.

16. Goldberg D, Hillier VF. A scaled version of the General Health Questionnaire. Psychol Med 1979; 9: 139-145.

17. Makowska Z, Merecz D. Ocena zdrowia psychicznego na podstawie badań kwestionariuszami Davida Goldberga. Podręcznik dla użytkowników kwestionariuszy GHQ-12 i GHQ-28 [Mental health assessment based on David Goldberg questionnaires GHQ-12 and GHQ-28. User Manual]. Łódź: Instytut Medycyny Pracy; 2001.

18. Holden R, Mehta K, Cunningham EJ, McLeod LD. Development and preliminary validation of a scale of psychache. Can J Behav Sci 2001; 33: 224-232.

19. Chodkiewicz J, Miniszewska J, Strzelczyk D, Gąsior K. Polska adaptacja Skali Bólu Psychicznego Ronalda Holdena i współpracowników [Polish adaptation of the Psychache Scale by Ronald Holden and co-workers]. Psychiatr Pol 2016; 40: 1-13.

20. Troister T, Holden R. Comparing psychache, depression, and hopelessness in their associations with suicidality: A test of Shneidman's theory of suicide. Pers Individ Dif 2010; 49: 689-693.

21. Stromberg R, Backlund LG, Lofvander MA. Comparison between the Beck's Depression Inventory and the Gotland Male Depression Scale in detecting depression among men visiting a drop-in clinic in primary care. Nordic J Psychiatry 2010; 64: 258-264.

22. Pompili M, Innamorati M, Lamis DA, Erbuto D, Venturini P, Ricci F, et al. The associations among childhood maltreatment, "male depression" and suicide risk in psychiatric patients. Psychiatry Res 2014; 15: 571-578.

23. Pompili M, Innamorati M, Gonda X, Erbuto D, Forte A, Ricci F, et al. Characterization of patients with mood disorders for their prevalent temperament and level of hopelessness. J Affect Disord 2014; 144: 285-291.

24. Möller-Leimkühler AM, Yücel M. Male depression in females? J Affect Disord 2010; 121: 22-29.

25. Rice SM, Fallon BJ, Aucote HM, Möller-Leimkühler AM. Development and preliminary validation of the Male Depression Risk Scale: furthering the assessment of depression in men. J Affect Disord 2013; 151: 950-958.

26. Magovcevic M, Addis ME. The Masculine Depression Scale: development and psychometric evaluation. Psychol Men Masc 2008; 9: 117-132. 